\title{
Longitudinal infusion of a complex of insulin-like growth factor-I and IGF-binding protein-3 in five preterm infants: pharmacokinetics and short-term safety
}

\author{
David Ley', Ingrid Hansen-Pupp ${ }^{1}$, Aimon Niklasson², Magnus Domellöf ${ }^{3}$, Lena E. Friberg ${ }^{4}$, Jan Borg ${ }^{5}$, Chatarina Löfqvist ${ }^{6}$,
} Gunnel Hellgren², Lois E.H. Smith7 , Anna-Lena Hård ${ }^{6}$ and Ann Hellström

BACKGROUND: In preterm infants, low levels of insulin-like growth factor-I (IGF-I) and IGF binding protein 3 (IGFBP-3) are associated with impaired brain growth and retinopathy of prematurity (ROP). Treatment with IGF-I/IGFBP-3 may be beneficial for brain development and may decrease the prevalence of ROP.

METHODS: In a phase II pharmacokinetics and safety study, five infants (three girls) with a median (range) gestational age (GA) of $26 w k+6 d(26 w k+0 d$ to $27 w k+2 d)$ and birth weight of $990(900-1,212) \mathrm{g}$ received continuous intravenous infusion of recombinant human (rh)|GF-I/rhlGFBP-3. Treatment was initiated during the first postnatal day and continued for a median (range) duration of $168(47-168) \mathrm{h}$ in dosages between 21 and $111 \mu \mathrm{g} / \mathrm{kg} / 24 \mathrm{~h}$.

RESULTS: Treatment with rhlGF-l/rhlGFBP-3 was associated with higher serum IGF-I and IGFBP-3 concentrations $(P<0.001)$ than model-predicted endogenous levels. Of 74 IGF-I samples measured during study drug infusion, 37 (50\%) were within the target range, 4 (5\%) were above, and 33 (45\%) were below. The predicted dose of rhlGF-l/rhlGFBP-3 required to establish circulating levels of IGF-I within the intrauterine range in a 1,000 $\mathrm{g}$ infant was $75-100 \mu \mathrm{g} / \mathrm{kg} / 24 \mathrm{~h}$. No hypoglycemia or other adverse effects were recorded.

CONCLUSION: In this study, continuous intravenous infusion of rhlGF-l/rhlGFBP-3 was effective in increasing serum concentrations of IGF-I and IGFBP-3, and was found to be safe.

nsulin-like growth factor-I (IGF-I) is essential for fetal growth and development in late gestation $(1,2)$. During the third trimester, fetal IGF-I serum levels are positively correlated with gestational age (GA) and birth weight $(3,4)$. After preterm birth, serum concentrations of IGF-I fall rapidly below normal intrauterine levels $(5,6)$. These low levels have been found to be associated with slow weight gain and slow growth in head circumference and, later, with retinopathy of prematurity $(\mathrm{ROP})(7,8)$.
The free/unbound IGF-I is regulated by IGF-binding proteins (IGFBPs), of which IGFBP-3 is the main circulating carrier protein. IGFBP-3, together with IGF-I, binds to the acid labile subunit (ALS) to form a ternary complex that prolongs the half-life of IGF-I $(9,10)$. In addition, low serum IGFBP-3 levels in preterm infants have been shown to be associated with the development of ROP. In mice, IGFBP-3 has been shown to modulate cellular mechanisms, independent of IGF-I, and to promote retinal vascular regrowth in oxygen-induced retinopathy (10).

For a better understanding of the pharmacokinetics of IGF-I and IGFBP-3 in preterm infants, we have previously performed two studies to evaluate the effects of transfusing fresh-frozen adult plasma (11) and infusing recombinant human (rh)IGF-1/ rhIGFBP-3 over a period of $3 \mathrm{~h}$ (12) on serum IGF-I/IGFBP-3 concentrations in preterm infants.

The administration of fresh-frozen plasma significantly increased the circulatory levels of IGF-I and IGFBP-3 in the preterm infants, suggesting that exogenous supplementation may counterbalance the immediate postnatal decrease of IGF-I and IGFBP-3 in these infants. Whereas the half-life of total IGF-I in adults has been calculated to be $\sim 17 \mathrm{~h}$ (13), the half-life of IGF-I in the preterm infants after plasma infusion was considerably shorter $(\sim 3 \mathrm{~h})$, suggesting that the administration of IGF-I to preterm infants should be performed via continuous intravenous infusion.

In the second study (12), five very preterm infants received a 3-h intravenous infusion of the drug mecasermin rinfabate, an equimolar preparation of recombinant protein complex of rhIGF-I and IGFBP-3, at a dose of 6-59 $\mu \mathrm{g} / \mathrm{kg} / 3 \mathrm{~h}$. The halflife of IGF- 1 was $<1 \mathrm{~h}$, and no adverse effects were observed.

This shows that the half-life of the IGF-I in intravenously administered mecasermin rinfabate is even shorter than that of the IGF-I in fresh-frozen plasma, indicating that administration via continuous infusion is necessary for achieving stable concentrations.

'Department of Pediatrics, Institution of Clinical Sciences, Lund University, Lund, Sweden; ${ }^{2}$ Department of Pediatrics, Institute of Clinical Sciences, Sahlgrenska Academy at the University of Gothenburg, Gothenburg, Sweden; ${ }^{3}$ Department of Clinical Sciences, Pediatrics, Umeå University, Umeå, Sweden; ${ }^{4}$ Department of Pharmaceutical Biosciences, Uppsala University, Uppsala, Sweden; ${ }^{5}$ Premacure AB, Uppsala Science Park, Uppsala, Sweden; ${ }^{6}$ Department of Ophthalmology, Institute of Neuroscience and Physiology, Sahlgrenska Academy at the University of Gothenburg, Gothenburg, Sweden; ${ }^{7}$ Department of Ophthalmology, Children's Hospital, Harvard Medical School, Boston, Massachusetts. Correspondence: David Ley (david.ley@med.lu.se) 
Table 1. Study subjects and study drug characteristics in five very preterm infants receiving longitudinal continuous infusion of IGF-I/IGFBP-3 complex

\begin{tabular}{|c|c|c|c|c|c|c|c|c|c|}
\hline $\begin{array}{l}\text { Patient } \\
\text { no. }\end{array}$ & Gender & $\begin{array}{l}\text { GA at birth } \\
\text { (weeks) }\end{array}$ & $\begin{array}{l}\text { Birth weight } \\
\text { (g) }\end{array}$ & $\begin{array}{l}\text { Birth weight } \\
\text { SDS }\end{array}$ & $\begin{array}{l}\text { Weight SDS at } \\
40 \text { wk PMA }\end{array}$ & $\begin{array}{l}\text { Infusion } \\
\text { duration (h) }\end{array}$ & $\begin{array}{c}\text { Doses Premiplex } \\
(\mu \mathrm{g} / \mathrm{kg} / 24 \mathrm{~h}) \\
\min -\max \end{array}$ & $\begin{array}{c}\text { Doses IGF-I } \\
(\mu \mathrm{g} / \mathrm{kg} / 24 \mathrm{~h}) \\
\min -\max \end{array}$ & $\begin{array}{l}\text { Total IGF-I } \\
\text { received }(\mu \mathrm{g})\end{array}$ \\
\hline 1 & Female & $26+6$ & 930 & -0.76 & -0.737 & 47.2 & 71-101 & $15-21$ & 33 \\
\hline 2 & Male & $26+5$ & 1,085 & 0.21 & 0.103 & 168.0 & $21-92$ & 4-19 & 113 \\
\hline 3 & Female & $26+6$ & 990 & -0.35 & -1.970 & 168.0 & $72-111$ & $15-23$ & 141 \\
\hline 4 & Male & $26+0$ & 900 & -0.38 & -1.817 & 123.9 & $66-100$ & $14-21$ & 95 \\
\hline
\end{tabular}

GA, gestational age; IGF-I, insulin-like growth factor-l; IGFBP-3, insulin-like growth factor-l binding protein 3; PMA, postmenstrual age; SDS, SD score.

The aim of the present study was to evaluate the pharmacokinetics and short-term safety of continuous infusion of rhIGF-I administered with its binding protein-3 (rhIGFBP-3) in a new cohort of very preterm infants.

\section{RESULTS}

\section{IGF-I and IGFBP-3 Pharmacokinetics}

The dose administered, the duration of infusion, and the serum IGF-1 concentrations attained during the study are presented in Table 1. The developed model, based on IGF-I serum concentration data from this study as well as from our earlier studies, predicted an initial exponential decline in the endogenous IGF-I levels (with a minimum at $\sim$ day 2 after birth), a return to the baseline birth values within $10 \mathrm{~d}$, and thereafter an increase with increasing birth weight. The endogenous concentrations $\left(C_{\text {endo }}\right)$ with increasing chronological age (Age) can be described as

$$
\begin{gathered}
C_{\text {endo }}=\left(C_{\text {endo, } 0} \cdot e^{-\mathrm{In} 2 / t_{1 / 20} \cdot \mathrm{Age}}\right)+C_{\text {endo,mat }} \\
\cdot\left(1-e^{-\mathrm{In} 2 / t_{1 / 2, \mathrm{mat}} \cdot \mathrm{Age}}\right) \cdot \mathrm{BW}^{\mathrm{POW}_{\text {endo }}}
\end{gathered}
$$

where $C_{\text {endo, } 0}$ is the endogenous concentration at birth and $C_{\text {endomat }}$ is the endogenous concentration approached after the initial phase, i.e., when the infants are more mature. The terms $t_{1 / 2,0}$ and $t_{1 / 2, \text { mat }}$ denote the half-lives of IGF- 1 for the initial decline and the following recovery phases, respectively. An identical model structure was chosen for IGFBP-3, although the exponent describing the weight dependence, $\mathrm{POW}_{\text {endo? }}$, ("power function of weight" dependence for endogenous IGF-1) was not significantly different from zero.

The concentrations of IGF-I and IGFBP-3 in serum increased significantly during infusion of an equimolar preparation of rhIGF-I/rhIGFBP-3 (Premiplex) $(P<0.001)$. The clearance $(\mathrm{CL})$ and distribution volume $(V)$ values for both IGF-I and IGFBP-3 were not significantly different from the values estimated in the phase I analysis (12) and were therefore fixed to those values so as to stabilize the model. Final parameter estimates are reported in Table 2, and individual data and model predictions are illustrated in Figure 1. As derived from the developed model, the predicted dose of the rhIGF-I/rhIGFBP complex required to establish circulating levels of IGF-I within the intrauterine range in a 1,000-g infant was between 75 and $100 \mu \mathrm{g} / \mathrm{kg} / \mathrm{d}$ (Figure 2).
Table 2. Final pharmacokinetic parameter estimates for endogenous

\begin{tabular}{|c|c|c|c|c|}
\hline & \multicolumn{2}{|l|}{ IGF-I } & \multicolumn{2}{|l|}{ IGFBP-3 } \\
\hline & $\begin{array}{c}\text { Typical } \\
\text { population value }\end{array}$ & $\begin{array}{c}\text { IIV } \\
(\mathrm{CV} \%)^{\mathrm{b}}\end{array}$ & Typical value & $\begin{array}{c}\text { IIV } \\
(\mathrm{CV} \%)^{\mathrm{b}}\end{array}$ \\
\hline $\mathrm{CL}(\mathrm{l} / 1 \mathrm{~kg})$ & $0.0924^{\mathrm{a}}$ & $31^{\mathrm{a}}$ & $0.0674^{\mathrm{a}}$ & NS \\
\hline$V(\mathrm{l} / \mathrm{kg})$ & $0.114^{\mathrm{a}}$ & NS & $0.0726^{a}$ & NS \\
\hline $\begin{array}{l}C_{\text {endo,o }} \\
(\mu \mathrm{g} / \mathrm{l} / 1 \mathrm{~kg})\end{array}$ & $17.5(16.6-20.4)$ & 63 & $1108(801-1,740)$ & 36 \\
\hline $\begin{array}{l}C_{\text {endo,mat }} \\
(\mu \mathrm{g} / \mathrm{l} / 1 \mathrm{~kg})\end{array}$ & $17.5(15.5-19.7)$ & 28 & $1103(986-1,259)$ & 22 \\
\hline$t_{1 / 2,0}$ (days) & $0.649(0.421-0.921)$ & 120 & $1.39(0.94-2.34)$ & 54 \\
\hline$t_{1 / 2, \text { mat }}$ (days) & $2.57(2.12-3.24)$ & 44 & $4.38(3.27-6.59)$ & 88 \\
\hline $\mathrm{POW}_{\text {endo }}$ & $0.529(0.410-0.549)$ & NS & 0 (Fixed) & NS \\
\hline $\begin{array}{l}\text { Proportional } \\
\text { residual error (\%) }\end{array}$ & $26.3(25.1-28.8)$ & NS & $13.7(12.3-15.3)$ & NS \\
\hline
\end{tabular}
IGF-I and IGFBP-3 (95\% Cl obtained by log-likelihood profiling)

$C_{\text {endo, }}$ concentration of endogenous IGF-I at birth; $C_{\text {endomat' }}$ concentration of endogenous IGF-l in more mature infants; $\mathrm{Cl}$, confidence interval; $\mathrm{CL}$, clearance; $\mathrm{CV}$, coefficient of variation; IGF-l, insulin-like growth factor-l; IGFBP, insulin-like growth factor-l binding protein 3 ; IIV, interindividual variability; NS, not statistically significant; $\mathrm{POW}$ endo' function of weight dependence for endogenous IGF- 1 ; $t_{1 / 2}$, half-life; $V$, distribution volume. aValues were fixed to previous estimates in the final model. bIIV parameters related to endogenous levels were significantly correlated (2-99\%).

\section{Short-Term Safety}

During the study drug infusions, none of the infants developed hypoglycemia (blood glucose $<2.6 \mathrm{mmol} / \mathrm{l}$ ) and none had persisting hyperglycemia requiring insulin treatment. One infant (patient 4) developed hyperglycemia after withdrawal of the study drug infusion, and was treated with insulin (0.06-0.11 $\mathrm{E} / \mathrm{kg} / \mathrm{h}$ ) for $7 \mathrm{~d}$. The relationships between the values of serum IGF-I and plasma glucose concentrations during the study drug infusions are illustrated in individual graphs in Figure 3.

Before the start of the study drug infusion, three infants had received endotracheal surfactant (Curosurf, Chiesi, Italy) and were on ventilators because of clinical signs of respiratory distress syndrome. Overall, these infants were on ventilators for 4,23 , and $52 \mathrm{~d}$. The other two infants were treated with continuous positive airway pressure initially; one of these infants required ventilator treatment at $10 \mathrm{~d}$ postnatal age because of culture-verified septicemia (Staphylococcus aureus) and was successfully extubated to continuous positive airway pressure $3 \mathrm{~d}$ later. The other infant did not require ventilator treatment. 
a

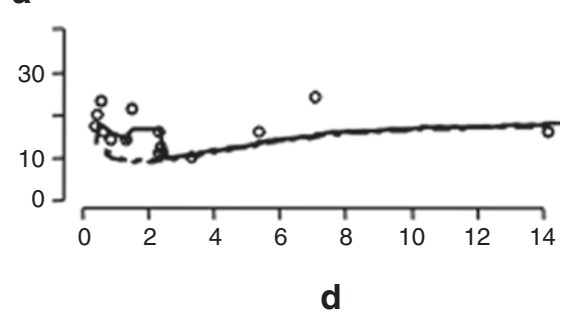

b

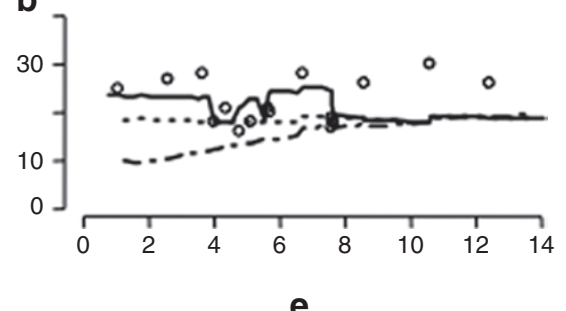

C

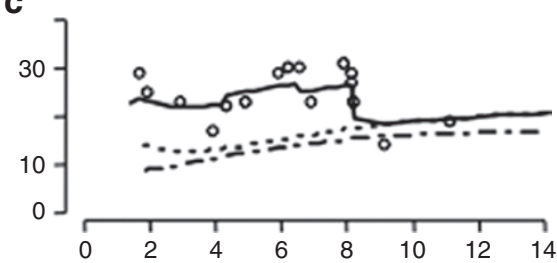

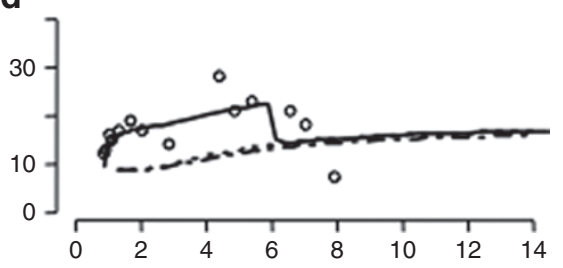

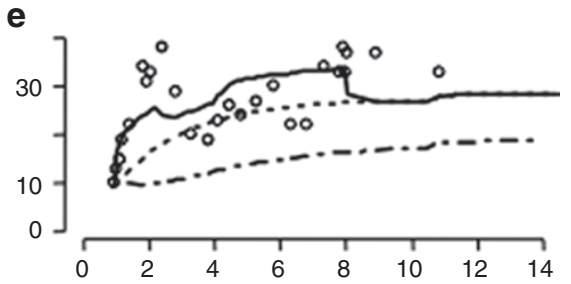

Figure 1. Observed and model-predicted serum insulin-like growth factor-I (IGF-I) concentrations, in relation to postnatal age, in five very preterm children. The chronological age (days) is shown on the $x$-axis and serum IGF-I levels ( $\mu \mathrm{g} / \mathrm{l}$ ) on the $y$-axis. (a) Patient 1; (b) patient 2; (c) patient 3; (d) patient 4; (e) patient 5. All the infants received continuous intravenous infusions of rhlGF-l/rhlGFBP-3. Population-predicted endogenous concentrations are shown for an untreated typical child with the same body weight as that of the treated subject. The individual predictions consider unexplained interindividual differences. The individual total predictions show the best model that fit the observed data and the administered doses of rhIGF-I/rhIGFBP-3. The observed values are depicted as circles, the individual-predicted endogenous serum IGF-I concentrations as a dotted line, the population-predicted endogenous serum IGF-I concentration as a broken line, and the individual-predicted total serum IGF-I as a solid line. rhIGF-I, recombinant human IGF-I; rhIGFBP, recombinant human IGF binding protein 3.

Two infants (patients 2 and 4) required supplemental oxygen at $36 \mathrm{wk}$ postmenstrual age (PMA); one of these infants was successfully weaned off supplemental oxygen at $39 \mathrm{wk}$ PMA. The other infant developed progressive chronic lung disease and died of severe respiratory insufficiency at a corrected age of $15 \mathrm{wk}$. The mother of this infant had a prenatal course of repeated vaginal hemorrhage from the 11th gestational week, genital chlamydia infection at 19 gestational wk, and premature rupture of membranes at 22 gestational wk.

None of the infants developed severe ROP or any degree of cerebral intraventricular hemorrhage, nor any evidence of intracranial hypertension as detected by clinical signs or increased ventricular size at ultrasound examinations. One infant (patient 1) had a suspected small thalamic hemorrhage noted on ultrasound on day 1 before the study drug infusion, and this was later confirmed with magnetic resonance imaging at term age. None of the infants developed signs of tonsillar hypertrophy.

The five children had a median caloric intake of $84 \mathrm{kcal} /$ $\mathrm{kg} / 24 \mathrm{~h}$, a median protein intake of $3.3 \mathrm{~g} / \mathrm{kg} / 24 \mathrm{~h}$, a median parenteral glucose intake of $6.2 \mathrm{mg} / \mathrm{kg} / \mathrm{min}$, and a median fluid intake of $160 \mathrm{ml} / \mathrm{kg} / 24 \mathrm{~h}$ (based on mean values on postnatal days 1-7). The infants had achieved total enteral nutrition at a median (range) postnatal age of 18 (14-42) d. The median (range) of the SD scores for weight at $40 \mathrm{wk}$ PMA was $-1.2(0.7$ to -1.8 ), Table 1 . The results from this first section of the study did not raise any safety concerns from the members of the safety committee.

\section{DISCUSSION}

In this study, we found that continuous intravenous infusion of an equimolar preparation of rhIGF-I/rhIGFBP-3 (Premiplex) in doses ranging between 21 and $111 \mu \mathrm{g} / \mathrm{kg} / 24 \mathrm{~h}$ in extremely

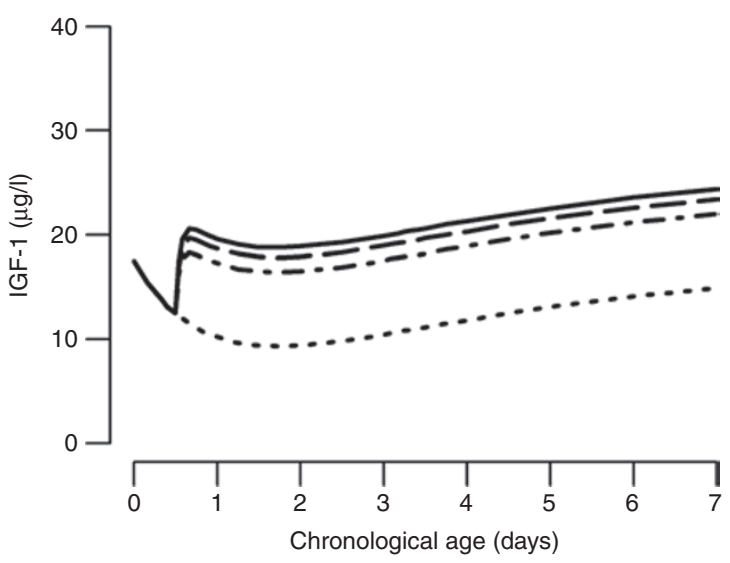

Figure 2. Predicted total and endogenous serum insulin-like growth factor-I (IGF-I) concentrations during continuous intravenous infusion of rhIGF-I/ rhlGFBP-3 at doses of 75,90 , and $100 \mu \mathrm{g} / \mathrm{kg} / 24 \mathrm{~h}$, started at $12 \mathrm{~h}$ after birth, in an infant with a birth weight of $1,000 \mathrm{~g}$. The endogenous IGF-I levels are depicted as a dotted line, the endogenous levels $+75 \mu \mathrm{g} / \mathrm{kg} / 24 \mathrm{~h}$ at $12 \mathrm{~h}$ are depicted as a dash-and-dot line, the endogenous levels $+90 \mu \mathrm{g} / \mathrm{kg} / 24 \mathrm{~h}$ at $12 \mathrm{~h}$ are depicted as a broken line, and the endogenous levels + $100 \mu \mathrm{g} / \mathrm{kg} / 24 \mathrm{~h}$ at $12 \mathrm{~h}$ are depicted as a solid line. rhIGF-I, recombinant human IGF-I; rhIGFBP, recombinant human IGF binding protein 3.

preterm infants during the first week of life increased serum IGF-I concentrations to the lower end of the normal intrauterine range without any evident adverse effects.

The dosing and administration of the drug were based on pharmacokinetics data from two previous studies in very preterm neonates, the first involving infusion of fresh-frozen plasma (11) and the second involving a 3-h infusion of the complex IGF-I/IGFBP-3 (12). Pharmacokinetics modeling showed that administration of the complex IGF-I/IGFBP-3 had a significant impact on circulating levels of IGF-I and 
a

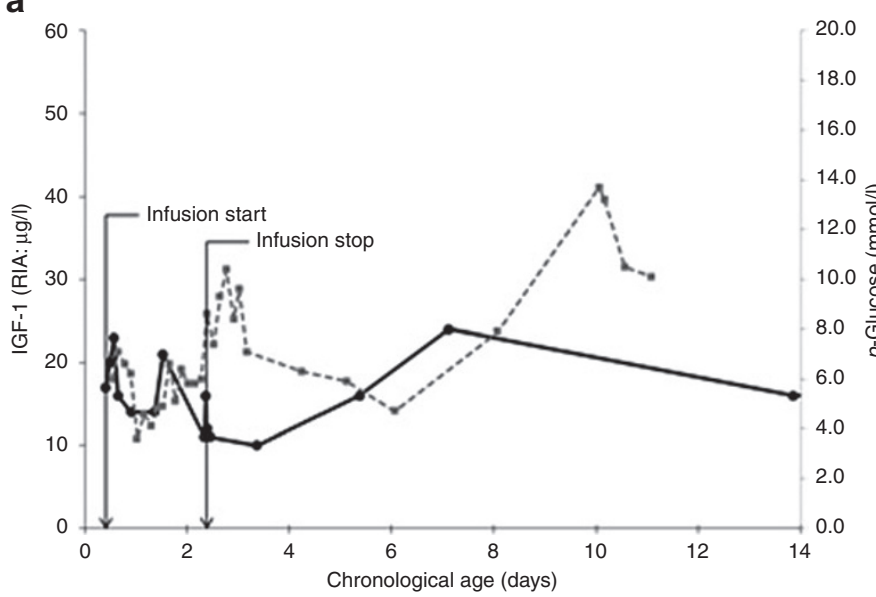

C

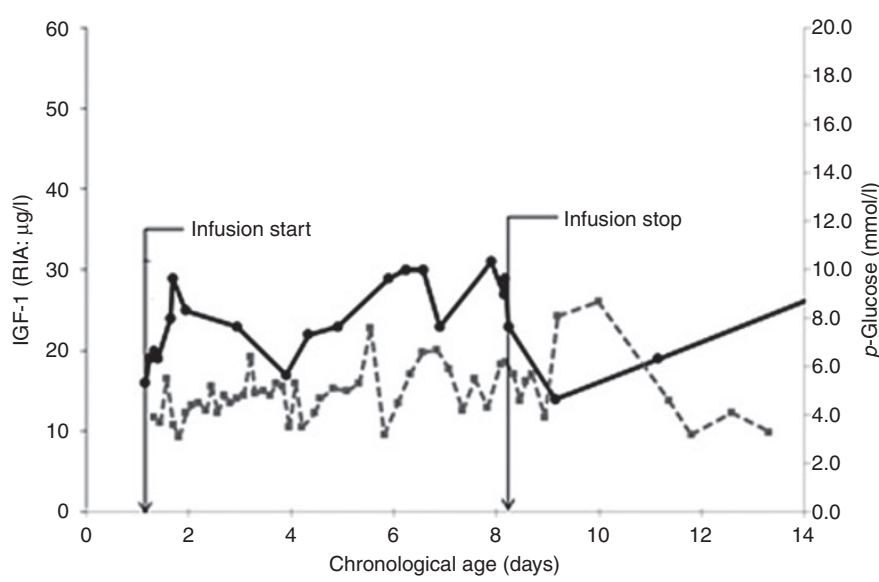

b
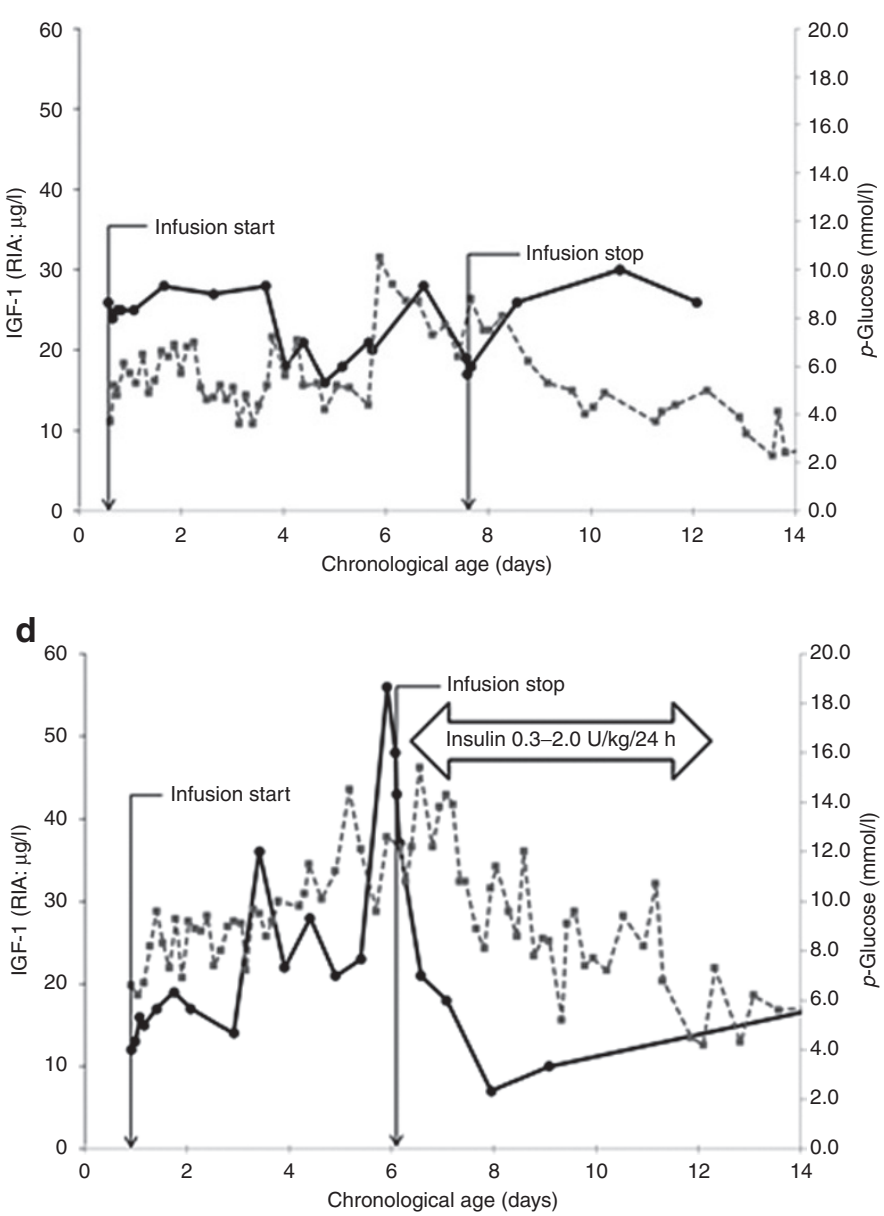

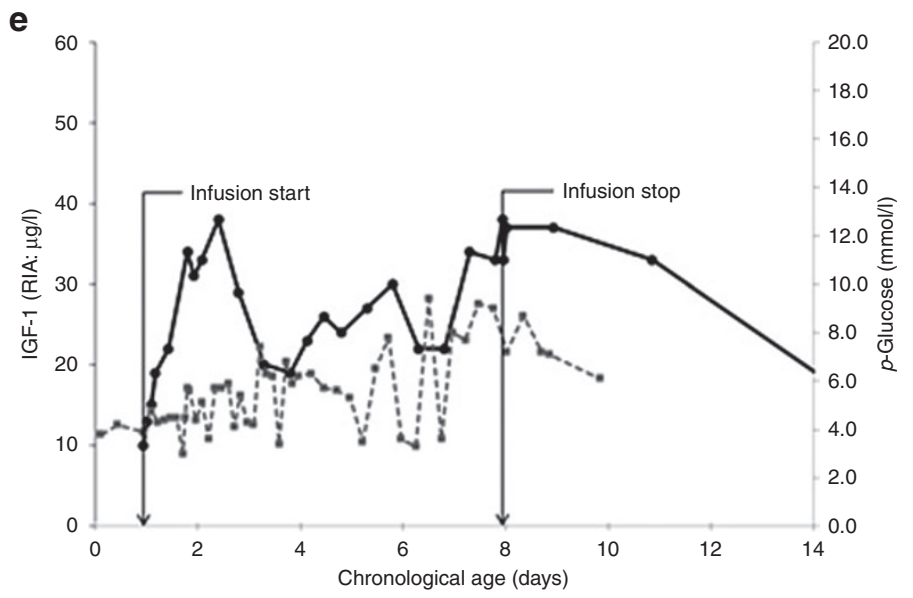

Figure 3. Longitudinal serum insulin-like growth factor-I (IGF-I) ( $\mu \mathrm{g} / \mathrm{l})$ (left $y$-axis), measured by radio-immunoassay, depicted as filled black circles connected with a solid black line, and plasma ( $p$-) glucose ( $\mathrm{mmol} / \mathrm{l})$ (right $y$-axis), depicted as filled gray squares connected with a dotted gray line, levels obtained during continuous infusion of rhIGF I/rhIGFBP-3 administered for 47-168h in five very preterm infants. (a) Patient 1; (b) patient 2; (c) patient 3; (d) patient 4; and (e) patient 5. Chronological ages at infusion start and infusion stop of rhlGF-I/rhlGFBP-3 infusions are indicated by black arrows. Insulin treatment is indicated by a large open arrow. rhIGF-I, recombinant human IGF-I; rhIGFBP, recombinant human IGF binding protein 3.

IGFBP-3. The developed model can be used for calculating the doses required to establish circulating levels that lie within the normal intrauterine range (Figure 2).

The half-life of free IGF-I in healthy adults is not more than $10-12 \mathrm{~min}$ (14). After a single intravenous dose of $40 \mu \mathrm{g} / \mathrm{kg}$ of rhIGF-I, the half-life of IGF- 1 was found to be $17.0 \pm 8.8 \mathrm{~h}$ in healthy adults, whereas in patients with growth hormone (GH) receptor deficiency the half-life of IGF-1 was substantially shorter, at $5.7 \pm 2.4 \mathrm{~h}(15)$. The three times higher CL of IGF-I in GH receptor deficiency was attributed to the low levels 
of IGFBP-3 in these patients. The rhIGF1/IGFBP-3 complex was developed with a view to increasing the serum half-life of IGF-I. In adolescents with GH insensitivity syndrome, a subcutaneous dose of $0.5 \mathrm{mg} / \mathrm{kg}$ of the complex rhIGF-I/IGFBP-3 (equivalent to $100 \mu \mathrm{g} / \mathrm{kg}$ rhIGF-I) resulted in an IGF-I half-life of $21 \pm 4 \mathrm{~h}$, which is similar to that observed in healthy adults receiving rhIGF-I only (16).

Grahnén et al. found similar values of IGF-I half-lives in healthy volunteers after subcutaneous and intravenous injection of $80 \mu \mathrm{g} / \mathrm{kg}$ of rhIGF-I; $18.9 \pm 5.2 \mathrm{~h}$ and $21.9 \pm 11.1 \mathrm{~h}$, respectively (15). In very preterm infants, intravenous administration of drugs is preferable to subcutaneous administration, given the sparseness of subcutaneous tissue.

In a previous study we had used the rhIGF-I/rhIGFBP-3 complex and had found a mean IGF-I half-life of $<1 \mathrm{~h}$ in preterm infants. This finding prompted us to move to the use of continuous intravenous infusion in our subsequent study (12). The causes for this rapid CL of IGF-I in very preterm infants are not known. It should be emphasized that, on the basis of allometric scaling theory, the half-life of exogenous IGF-I in a 1,000 g infant would be approximately one-third of that in a $70 \mathrm{~kg}$ adult (17).

It appears that the half-life of administered IGF-I in the circulation decreases with both decreasing body weight and decreasing GA at birth (11). The formation of the ternary complex with the ALS maintains the rhIGF-I in bound form in the circulation and, in adults, extends the half-lives of the IGFs from $10 \mathrm{~min}$ in free form and 20-30 min in binary complexes to more than $12 \mathrm{~h}$ (14). Like IGF-I, ALS is secreted by the liver in response to GH binding to its receptor (18). In the cord serum of a neonate at 27 wk of gestation, no ternary complex formation was apparent and ALS was undetectable (19). The most likely explanation for the short half-life of IGF-1 in our study patients is that IGF-I circulates mainly in binary rather than ternary complexes, as obtains in fetuses of corresponding GAs.

We have previously found low levels of ALS in preterm infants (unpublished data). Preterm infants frequently exhibit an increased systemic proinflammatory response during the first postnatal week, with a potential for induction of protease activity; the proteolysis of IGFBP-3, in turn, decreases the halflife of IGF-I (5).

The rhIGF-I/rhIGFBP-3 complex was developed to reduce the side effects seen after rhIGF-I administration. In severely burned children, treatment with the complex reversed catabolism and the side effects were negligible (20). In children with GH insensitivity syndrome, rhIGF-I/IGFBP-3 was effective in increasing circulating levels of total and free IGF-I to the normal range without acute side effects. The postnatal period after extremely preterm birth is characterized by catabolism and deranged glucose metabolism, with insulin resistance and hyperglycemia (21), as well as by GH resistance (22). Attempts to improve growth and metabolism have included increased nutritional inputs and insulin treatment. However, in the most immature babies, nutrient intake in the early neonatal period of growth restriction appears to have a limited effect on growth and on IGF-I, while IGF-I levels are associated with growth
(23). In the NIRTURE study, early continuous insulin infusion during the first weeks of life reduced hyperglycemia and increased IGF-I levels; however, no clinical benefit was found, and mortality was higher at $28 \mathrm{~d}$ in the early insulin group (17). The anabolic effects of insulin are mediated by an inhibition of protein catabolism, in contrast to those of IGF-I, which appear to be the result of stimulation of protein synthesis (24). In preterm babies, insulin treatment has been found to be a stronger risk factor for ROP than hyperglycemic episodes per se (25).

In this study, IGF-I supplementation took place at a PMA of approximately $27 \mathrm{wk}$ and was discontinued after $7 \mathrm{~d}$ per the protocol. We have previously shown that decreased levels of IGF-I during postnatal development are associated with signs of impaired brain growth (as determined by lower head circumference and magnetic resonance imaging evidence at term age) and also with severe $\operatorname{ROP}(7,8,26)$. Our hypothesis is that if Premiplex infusion during the first weeks of life can promote nutrient utilization, metabolism, growth, and endogenous IGF-I synthesis, there will be a reduction in the morbidity associated with low serum IGF-I concentrations at 30-33 wk PMA (7), when the SD scores for weight normally start to increase (23) and ROP starts to develop. In a study in newborn mice, neonatal administration of IGF-I resulted in increased growth, reduced susceptibility to oxygen-induced retinopathy, and increased endogenous levels of IGF-I (27).

Our pharmacokinetics study involving five very preterm infants is too small for a determination of the efficacy of this approach. However, all the infants in our study had an acceptable glycemic control during infusion of the study drug. Of note, none of them registered hypoglycemia, and no adverse events were observed.

After completion of $7 \mathrm{~d}$ of infusion of the study drug, serum IGF-I levels fell below intrauterine concentrations for corresponding GA, indicating that infusion should be continued for $>7 \mathrm{~d}$ to maintain physiologic IGF-I concentrations during the early postnatal period. A future study will evaluate optimal treatment duration and therapeutic interval, and assess the efficacy of prolonged continuous administration of IGF-I in very preterm infants.

\section{MATERIALS AND METHODS \\ Study Subjects}

A total of five infants were recruited to the study, which was conducted at the neonatal unit at Skane University Hospital, Lund, Sweden, a referral center for southern Sweden, between June 2010 and June 2011. Inclusion criteria were GA at birth between $26 \mathrm{wk}+0 \mathrm{~d}$ and $27 \mathrm{wk}+6 \mathrm{~d}$ (GA estimated by ultrasound in pregnancy week 17), and a birth weight $>-2$ SD and $<+2$ SD based on $z$ score for age and sex (28).

The children were enrolled either before or immediately after delivery. Exclusion criteria were severe malformation, known or suspected chromosomal abnormality, or the presence of a genetic disorder or syndrome according to the investigator's opinion.

The five patients (three females and two males) had a median GA of $26 \mathrm{wk}+6 \mathrm{~d}$ and a median birth weight of $990 \mathrm{~g}$. The clinical characteristics of the five infants are given in Table 1 . The study was approved by the Regional Ethical Review Board in Göteborg, and by the Swedish Medical Products Agency. The study was monitored by Pharmaconsulting Group AB (Uppsala, Sweden), and electronic case record forms (Viedoc) from that company were used. The parents of all the participants gave their written informed consent before the start of the study. 


\section{Preparation of rhIGF-I/rhIGFBP-3}

The study drug (Premiplex, Premacure AB, Uppsala, Sweden) was manufactured from the drug substance mecasermin rinfabate (International Nonproprietary Name, United States Adopted Name) with infusion solution $60 \mathrm{mg} / \mathrm{ml}$ (Insmed, Richmond, VA). Mecasermin rinfabate is an equimolar preparation of a recombinant protein complex of rhIGF-I and rhIGFBP-3. Premiplex was formulated as a sterile, preservativefree, clear solution composed of $50 \mu \mathrm{g} / \mathrm{ml}$ of the active ingredients in $50 \mathrm{mmol} / \mathrm{l}$ sodium acetate, $105 \mathrm{mmol} / \mathrm{l}$ sodium chloride, and $\mathrm{pH}$ 5.5 buffer, with an osmolality of $\sim 290 \mathrm{mOsm} / \mathrm{kg}$. The contents of the Premiplex (Lot FAH1001) vials were diluted with $10 \%$ glucose solution to patient-individualized concentrations and administered at individualized infusion rates. For infusion, the solution was transferred to an infusion pump, Alaris Asena CC or IVAC P 7000 syringe pump (Alaris, Medical Systems, Hampshire, UK), which was connected to a syringe extension set and filled with the infusion solution. The syringe and extension set were saturated for $1 \mathrm{~h}$, and thereafter connected to an umbilical venous catheter (Vygon, Swindon, UK) with the pump adjusted to administer the calculated dose.

The processes for the manufacture and purification of rhIGF-I/ rhIGFBP-3 have been described previously (16).

\section{Study Design}

The desired target serum levels of IGF-I were based on previously published intrauterine levels for corresponding GA (6), and set at $15 \%$ below the mean with a range of $\pm 25 \%$. In order to bring IGF-I into the target range (20-40 $\mu \mathrm{g} / \mathrm{l})$, administration of the rhIGF-I/rhIGFBP3 -glucose solution was started at a median (range) postnatal age of $19.0(9.8-27.5) \mathrm{h}$. Blood samples $(0.2 \mathrm{ml})$ for determination of serum IGF-I and IGFBP-3 were drawn immediately before and at 2, 4, 6, and $12 \mathrm{~h}$ after the start of the infusion. After change of infusion solutions, samples were taken every 24 as well as $4 \mathrm{~h}$ after change of Premiplex dose. Samples were also obtained immediately before the start of the last infusion, at $0.5,2,24$, and $72 \mathrm{~h}$ after the completion, and thereafter once weekly (up to $40 \mathrm{wk}$ PMA). Individualized dosing and dilution instructions were obtained from computer software (3p2) designed for the study.

Arterial blood samples for determination of $p$-glucose were obtained after insertion of umbilical catheters and during infusion of study drug once every third hour for $3 \mathrm{~d}$, and thereafter once every sixth hour for $4 \mathrm{~d}$. The samples were drawn before enteral feeding. If $p$-glucose was $<3 \mathrm{mmol} / \mathrm{l}$, measurements were performed once every hour until the level was $>3 \mathrm{mmol} / \mathrm{l}$. After termination of the study drug infusion, $p$-glucose was measured once every third hour for the first $12 \mathrm{~h}$ and thereafter once every $6 \mathrm{~h}$ during the following $12 \mathrm{~h}$. If the meal intervals were other than $3 \mathrm{~h}$, the timings of $p$-glucose measurement were adjusted accordingly. Samples for measurement of insulin concentrations were to be taken when $p$-glucose concentrations were $<2.6 \mathrm{mmol} / \mathrm{l}$.

Vital signs (heart rate, blood pressure, and oxygen saturation levels) were recorded once every hour during the first $24 \mathrm{~h}$, and thereafter once every third hour up to the termination of the study drug infusion. Diuresis $(\mathrm{ml} / \mathrm{kg} / 24 \mathrm{~h})$ was registered. Echocardiography for detection of persistent ductus arteriosus was performed per the clinical routine on postnatal days $1-3$.

Weight, length, and head circumference measurements were carried out daily from birth to study day 7 , and thereafter twice a week up to 40 wk PMA. SD scores were calculated for measurements of each growth parameter based on gender-specific growth reference curves relating to a Swedish population (29).

Parenteral and enteral nutrition were administered in accordance with a standardized protocol aimed at an early attainment of optimized total nutritional intake. Target intakes were set to $40-50 \mathrm{kCal} /$ $\mathrm{kg} / \mathrm{d}$ and $1.5-2.5 \mathrm{~g}$ protein $/ \mathrm{kg} / \mathrm{d}$ (day 1 ), $90-100 \mathrm{kCal} / \mathrm{kg} / \mathrm{d}$ and $3-4 \mathrm{~g}$ protein $/ \mathrm{kg} / \mathrm{d}$ (day 4), and a final target of $120 \mathrm{kCal} / \mathrm{kg} / \mathrm{d}$ and $4.0-4.5 \mathrm{~g}$ protein $/ \mathrm{kg} / \mathrm{d}$.

Repeated brain ultrasound examinations (8.5 MHz probe, Acuson Sequoia, Mountain View, CA) were performed by a neonatologist and re-evaluated by a pediatric radiologist before the study drug infusion and on days 3, 7, 14,21, at PMA 6 wk after birth and at term age (40 wk PMA). Severe intracranial hemorrhage was defined as the presence of intraventricular hemorrhage grade III or periventricular hemorrhagic infarction and white matter damage in the presence of periventricular echodensities persisting for more than $7 \mathrm{~d}$, or the presence of periventricular cysts. Signs of intracranial hypertension were defined as the presence of increased ventricular size and were to be recorded as an adverse event. Magnetic resonance imaging of the brain was performed at $40 \mathrm{wk}$ PMA. The infants underwent a neurological and somatic examination at term age including oral inspection for tonsillar hypertrophy.

The safety committee scrutinized the study data of each infant treated. After the inclusion of the five infants, the safety committee provided a safety report.

\section{Calculation of Study Drug Dose}

In previous pharmacokinetics and dose-finding studies $(11,12)$, onecompartment models with linear elimination of parameters were sufficient to describe the data of IGF-I and IGFBP-3 concentrations vs. time. The endogenous serum baseline concentration, $\mathrm{CL}_{1 \mathrm{~kg}}$, and distribution volume $\left(V_{1 \mathrm{~kg}}\right)$ for IGF-I were estimated to be $18.8 \mu \mathrm{g} / \mathrm{l}$, $0.0924 \mathrm{l} / \mathrm{h} / \mathrm{kg}$, and $0.114 \mathrm{~kg} / \mathrm{kg}$, respectively, with a calculated halflife of $0.86 \mathrm{~h}$ for a typical infant of body weight $1,000 \mathrm{~g}$. The initial dose of IGF-1 to be administered was determined on the basis of the infant's PMA, the intrauterine IGF-I serum levels for corresponding GA, and the infant's current weight. Subsequent dose calculations also included actual endogenous levels of IGF-I.

Dose adjustments ( $5 \mathrm{~h}$ after blood sampling) were carried out depending on the measured serum IGF-I level at $4 \mathrm{~h}$ after the start of each new infusion. Dose modifications were in accordance with the magnitude of deviation from targeted levels; a 100\% decrease and a maximum of $50 \%$ increase in the dose were allowed.

\section{Analysis of IGF-I and IGFBP-3}

Serum samples for IGF-I and IGFBP-3 analyses were obtained from an umbilical arterial catheter or a peripheral arterial line. Total serum IGF-I and IGFBP-3 concentrations were analyzed using IGFBP-blocked radio-immunoassay and a specific radio-immunoassay (Mediagnost, Tübingen, Germany). The IGF-I samples were diluted 1:50 and the IGFBP-3 samples were diluted 1:300. The intra-assay coefficients of variation for IGF-I were 18, 11, and $7 \%$ at concentrations of 9,33 , and $179 \mu \mathrm{g} / \mathrm{l}$, respectively. The intra-assay coefficients of variations for IGFBP-3 were 10, 7, and $6 \%$ at concentrations of 716, 1,750, and $3,929 \mu \mathrm{g} / \mathrm{l}$, respectively. All samples were analyzed in the same assay. The methods have been described in detail previously (30).

\section{Pharmacokinetics Modeling}

All serum concentration values of IGF-I and IGFBP-3 including available data from a Phase I study (12) and longitudinal descriptive IGF-I studies $(5,7,23)$ were analyzed using nonlinear mixed-effects modeling and the first-order conditional estimation method in NONMEM 7 (31). Endogenous serum concentrations of IGF-I and IGFBP-3 were estimated using a range of different models, including those describing exponential and linear declines of IGF-1 concentrations after birth followed by a subsequent increase.

The pharmacokinetic characteristics of the infused IGF-I and IGFBP-3 were described by compartmental modeling. One- and two-compartment models with linear or nonlinear elimination were evaluated.

The choice of structural model, inclusion of between-subject variability in the parameters, and the choice of additive and/or proportional residual error models were tested for statistical significance, using the minimum objective function value produced by NONMEM. A drop of 6.63 in objective function value, which corresponds to a significance level of $P<0.01$, was required for adding one extra parameter. CL and volume $(V)$ terms were scaled allometrically by body weight (32).

$$
\begin{aligned}
\mathrm{CL} & =\mathrm{CL}_{1 \mathrm{~kg}} \cdot \text { weight }^{0.75} \\
V & =V_{1 \mathrm{~kg}} \cdot \text { weight }
\end{aligned}
$$

Individual pharmacokinetics parameters of IGF-I and IGFBP-3 were derived using the POSTHOC step in NONMEM. The halflife was computed as $t_{1 / 2}=\ln (2) \cdot V / C L$, and the area under the 
concentration-time curve resulting from $24 \mathrm{~h}$ mecasermin rinfabate infusion $\left(\mathrm{AUC}_{24}\right)$ was computed as $\mathrm{AUC}_{24}=$ Dose $_{24} / \mathrm{CL}$.

\section{Statistics}

All data are expressed as median and range. Predominantly descriptive statistics are presented.

\section{STATEMENT OF FINANCIAL SUPPORT}

This study was supported by the Swedish Medical Research Council (grant 2008-2842, 14940), government grants (ALFGB-21611), VINNOVA (grant 2009-01152, 2009-00221), the Torsten and Ragnar Söderberg Foundation, the Skåne Council Foundation for Research and Development, and the Linnéa and Josef Carlsson Foundation.

Disclosure: The application to prevent retinopathy of prematurity by means of administering IGF-I is covered by patents and patent applications owned by Children's Medical Center Corporation, Boston, MA, and Premacure AB, Uppsala, Sweden. Six of the authors (I.H.-P., C.L., A.-L.H., A.H., D.L., and J.B.) own shares in a company controlling Premacure AB. The remaining authors have nothing to declare.

\section{ACKNOWLEDGMENTS}

The authors thank Ann-Cathrine Berg and Eva Hammarstrand for their assistance in clinical data collection and Lisbeth Larsson for her assistance in analyzing the IGF-I and IGFBP-3 samples. Clinical trial registration number: NCT01096784.

\section{REFERENCES}

1. Gluckman PD. Clinical review 68: the endocrine regulation of fetal growth in late gestation: the role of insulin-like growth factors. J Clin Endocrinol Metab 1995;80:1047-50.

2. Netchine I, Azzi S, Le Bouc Y, Savage MO. IGF1 molecular anomalies demonstrate its critical role in fetal, postnatal growth and brain development. Best Pract Res Clin Endocrinol Metab 2011;25:181-90.

3. Ashton IK, Zapf J, Einschenk I, MacKenzie IZ. Insulin-like growth factors (IGF) 1 and 2 in human foetal plasma and relationship to gestational age and foetal size during midpregnancy. Acta Endocrinol 1985;110:558-63.

4. Lassarre C, Hardouin S, Daffos F, Forestier F, Frankenne F, Binoux M. Serum insulin-like growth factors and insulin-like growth factor binding proteins in the human fetus. Relationships with growth in normal subjects and in subjects with intrauterine growth retardation. Pediatr Res 1991;29:219-25.

5. Hansen-Pupp I, Hellström-Westas L, Cilio CM, Andersson S, Fellman V, Ley D. Inflammation at birth and the insulin-like growth factor system in very preterm infants. Acta Paediatr 2007;96:830-6.

6. Langford K, Nicolaides K, Miell JP. Maternal and fetal insulin-like growth factors and their binding proteins in the second and third trimesters of human pregnancy. Hum Reprod 1998;13:1389-93.

7. Hellström A, Engström E, Hård AL, et al. Postnatal serum insulin-like growth factor I deficiency is associated with retinopathy of prematurity and other complications of premature birth. Pediatrics 2003;112:1016-20.

8. Löfqvist C, Engström E, Sigurdsson J, et al. Postnatal head growth deficit among premature infants parallels retinopathy of prematurity and insulinlike growth factor-1 deficit. Pediatrics 2006;117:1930-8.

9. Holly J, Perks C. The role of insulin-like growth factor binding proteins. Neuroendocrinology 2006;83:154-60.

10. Lofqvist C, Chen J, Connor KM, et al. IGFBP3 suppresses retinopathy through suppression of oxygen-induced vessel loss and promotion of vascular regrowth. Proc Natl Acad Sci USA 2007;104:10589-94.

11. Hansen-Pupp I, Engström E, Niklasson A, et al. Fresh-frozen plasma as a source of exogenous insulin-like growth factor-I in the extremely preterm infant. J Clin Endocrinol Metab 2009;94:477-82.

12. Löfqvist C, Niklasson A, Engström E, et al. A pharmacokinetic and dosing study of intravenous insulin-like growth factor-I and IGF-binding protein-3 complex to preterm infants. Pediatr Res 2009;65:574-9.
13. Mizuno N, Kato Y, Iwamoto M, et al. Kinetic analysis of the disposition of insulin-like growth factor 1 in healthy volunteers. Pharm Res 2001;18:1203-9.

14. Guler HP, Zapf J, Schmid C, Froesch ER. Insulin-like growth factors I and II in healthy man. Estimations of half-lives and production rates. Acta Endocrinol 1989;121:753-8.

15. Grahnén A, Kastrup K, Heinrich U, et al. Pharmacokinetics of recombinant human insulin-like growth factor I given subcutaneously to healthy volunteers and to patients with growth hormone receptor deficiency. Acta Paediatr Suppl 1993;82:suppl 391:9-13; discussion 14.

16. Camacho-Hübner C, Rose S, Preece MA, et al. Pharmacokinetic studies of recombinant human insulin-like growth factor I (rhIGF-I)/rhIGF-binding protein-3 complex administered to patients with growth hormone insensitivity syndrome. J Clin Endocrinol Metab 2006;91:1246-53.

17. Beardsall K, Vanhaesebrouck S, Ogilvy-Stuart AL, et al. A randomised controlled trial of early insulin therapy in very low birth weight infants, "NIRTURE" (neonatal insulin replacement therapy in Europe). BMC Pediatr 2007;7:29.

18. Boisclair YR, Rhoads RP, Ueki I, Wang J, Ooi GT. The acid-labile subunit (ALS) of the $150 \mathrm{kDa}$ IGF-binding protein complex: an important but forgotten component of the circulating IGF system. J Endocrinol 2001;170:63-70.

19. Lewitt MS, Scott FP, Clarke NM, Baxter RC. Developmental regulation of circulating insulin-like growth factor-binding proteins in normal pregnancies and in pre-eclampsia. Prog Growth Factor Res 1995;6:475-80.

20. Herndon DN, Ramzy PI, DebRoy MA, et al. Muscle protein catabolism after severe burn: effects of IGF-1/IGFBP-3 treatment. Ann Surg 1999;229:713-20; discussion 720-2.

21. Beardsall K, Ogilvy-Stuart AL, Frystyk J, et al. Early elective insulin therapy can reduce hyperglycemia and increase insulin-like growth factor-I levels in very low birth weight infants. J Pediatr 2007;151:611-7, 617.e1.

22. Hikino S, Ihara K, Yamamoto J, et al. Physical growth and retinopathy in preterm infants: involvement of IGF-I and GH. Pediatr Res 2001;50:732-6.

23. Hansen-Pupp I, Löfqvist C, Polberger S, et al. Influence of insulin-like growth factor I and nutrition during phases of postnatal growth in very preterm infants. Pediatr Res 2011;69(5 Pt 1):448-53.

24. Fryburg DA, Jahn LA, Hill SA, Oliveras DM, Barrett EJ. Insulin and insulin-like growth factor-I enhance human skeletal muscle protein anabolism during hyperaminoacidemia by different mechanisms. J Clin Invest 1995;96:1722-9.

25. Kaempf JW, Kaempf AJ, Wu Y, Stawarz M, Niemeyer J, Grunkemeier G. Hyperglycemia, insulin and slower growth velocity may increase the risk of retinopathy of prematurity. J Perinatol 2011;31:251-7.

26. Hansen-Pupp I, Hövel H, Hellström A, et al. Postnatal decrease in circulating insulin-like growth factor-I and low brain volumes in very preterm infants. J Clin Endocrinol Metab 2011;96:1129-35.

27. Vanhaesebrouck S, Daniëls H, Moons L, Vanhole C, Carmeliet P, De Zegher F. Oxygen-induced retinopathy in mice: amplification by neonatal IGF-I deficit and attenuation by IGF-I administration. Pediatr Res 2009;65:307-10.

28. Marsál K, Persson PH, Larsen T, Lilja H, Selbing A, Sultan B. Intrauterine growth curves based on ultrasonically estimated foetal weights. Acta Paediatr 1996;85:843-8.

29. Niklasson A, Albertsson-Wikland K. Continuous growth reference from $24^{\text {th }}$ week of gestation to 24 months by gender. BMC Pediatr 2008;8:8.

30. Blum WF, Breier BH. Radioimmunoassays for IGFs and IGFBPs. Growth Regul 1994;4:Suppl 1:11-9.

31. Beal S, Sheiner LB, Boeckmann, AJ. 1989-2006 NONMEM Users Guides. Ellicott City, Maryland: Icon Development Solutions, 1989-2006.

32. Anderson BJ, Holford NH. Mechanism-based concepts of size and maturity in pharmacokinetics. Annu Rev Pharmacol Toxicol 2008;48: 303-32. 